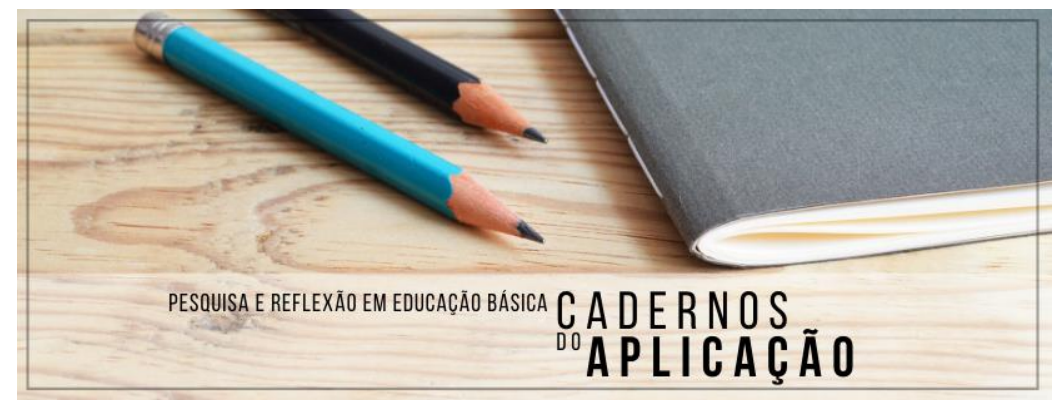

Cadernos do Aplicação

https://seer.ufrgs.br/CadernosdoAplicacao

Publicação Ahead of Print

ISSN 2595-4377 (online)

Porto Alegre | jul-dez. 2021 | v.34 | n.2

\title{
Trocando as lentes sobre a escola In/Exclusão em tempo de pandemia
}

José Blanes Sala ${ }^{1}$

William Vinicius Pinto ${ }^{2}$

\begin{abstract}
Resumo: Este trabalho de investigação estabelece a relação entre a medida socioeducativa em meio aberto e a escola, especificamente, no período da Pandemia da COVID-19 e promove uma análise e reflexão crítica sobre a estrutura da instituição escolar. A questão central é o lugar da escola desde a ótica dos adolescentes que estão sob a égide do Sistema de Justiça Juvenil-Socioeducativo. A pesquisa tomou como referência a pedagogia social espanhola e as obras de Paulo Freire, Pedagogia do Oprimido e Pedagogia da Autonomia. Realizou-se uma entrevista on-line e coletiva com o uso da plataforma Google Meet, participando de forma síncrona, os adolescentes em regime de restrição de liberdade em cumprimento de liberdade assistida, durante o periodo de uma hora e quarenta minutos. O resultado desse estudo proporciona a ruptura com o paradigma tradicional do que é a escola e, ao trocar as lentes, possibilita reconhecê-la de outro ponto de vista.
\end{abstract}

Palavras-chave: Adolescente. Medida socioeducativa. Escola. Pandemia da COVID-19.

\section{Swapping lenses over school In/Exclusion in pandemic time}

\begin{abstract}
This research work establishes the relationship between the socio-educational measure in an open environment and the school, specifically, in the period of the COVID-19 Pandemic and promotes a critical analysis and reflection on the structure of the school institution. The central issue is the place of the school from the perspective of adolescents who are under the aegis of the Juvenile Justice System - Socio-educational. The research took as reference the Spanish Social Pedagogy and the works of Paulo Freire, Pedagogy of the Oppressed and Pedagogy of Autonomy. An online and collective interview was conducted using the Google Meet platform, participating synchronously, the adolescents in a restriction of freedom in compliance with Assisted Freedom, during the period of one hour and forty minutes. The result of this study provides the break with the traditional paradigm of what the school is and, when changing the lenses, makes it possible to recognize it from another point of view.
\end{abstract}

\footnotetext{
${ }^{1}$ Mestre e Doutor pela Faculdade de Direito da USP; Professor Associado da Universidade Federal do ABC UFABC; Email: blanes@ufabc.edu.br; ORCID iD https://orcid.org/0000-0001-6671-9024

2 Doutorando em Ciências Humanas e Sociais pela Universidade Federal do ABC - UFABC, Mestre em Educação pela Universidade Nove de Julho, Graduado em Pedagogia pela Universidade do Grande ABC - UNIABC. Email: will_vinicius@hotmail.com; ORCID iD https://orcid.org/0000-0002-0641-893X
} 


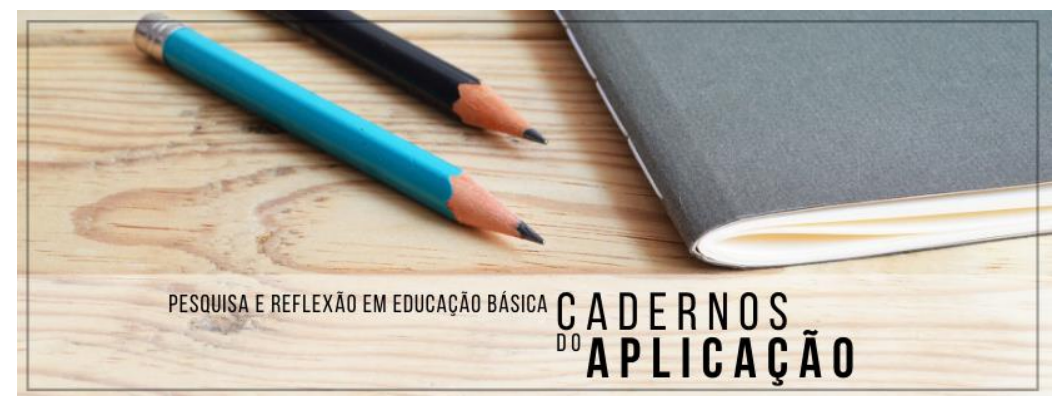

Cadernos do Aplicação https://seer.ufrgs.br/CadernosdoAplicacao

Publicação Ahead of Print

ISSN 2595-4377 (online)

Porto Alegre | jul-dez. 2021 | v.34 | n.2

Keywords: Adolescent. Socio-educational measure. School. COVID-19 pandemic.

\title{
Intercambio de lentes sobre la escuela In/Exclusión en tiempo de pandemia
}

\begin{abstract}
Resumen: Este trabajo de investigación establece la relación entre la medida socioeducativa en un entorno abierto y la escuela, específicamente, en el período de la Pandemia COVID-19 y promueve un análisis crítico y una reflexión sobre la estructura de la institución escolar. El tema central es el lugar de la escuela desde la perspectiva de los adolescentes que están bajo la égida del Sistema de Justicia Juvenil - Socioeducativo. La investigación tomó como referencia la Pedagogía Social Española y las obras de Paulo Freire, Pedagogía de los Oprimidos y Pedagógico de la Autonomía. Se realizó una entrevista en línea y colectiva utilizando la plataforma Google Meet, participando sincrónicamente, los adolescentes en una restricción de libertad en cumplimiento de la Libertad Asistida, durante el período de una hora y cuarenta minutos. El resultado de este estudio proporciona la ruptura con el paradigma tradicional de lo que es la escuela y, al cambiar las lentes, permite reconocerlo desde otro punto de vista.
\end{abstract}

Palabras clave: Adolescente. Medida socioeducación. Escuela. Pandemia COVID-19.

\section{Introdução}

O presente estudo está inscrito em temática presente cotidianamente em nossa sociedade, e tem como eixo norteador as ações sociopedagógicas desenvolvidas com um grupo específico de adolescentes autores de ato infracional, atendidos pela Fundação Criança de São Bernardo do Campo (FCSBC) $)^{3}$ por meio do Centro de Atendimento Socioeducativo (CASE), por determinação judicial.

O CASE, é um serviço que está inscrito no âmbito de atuação da proteção social especial (PSE) de média complexidade. Tem por objetivo o acompanhamento de forma qualificada aos(às) adolescentes e, ou, jovens, em cumprimento de medidas socioeducativas de liberdade assistida (LA) e prestação de serviços à comunidade (PSC), conforme determina a Tipificação Nacional de Serviços Socioassistenciais (2009) e atende 100\% da demanda encaminhada pelo

\footnotetext{
${ }^{3}$ Instituída em 26 de novembro de 1998, é uma fundação pública municipal com missão, diretrizes e objetivos focados na defesa e garantia de direitos de crianças, adolescentes e jovens.
} 
Poder Judiciário, diferentemente da maioria dos municípios brasileiros, onde são atendidos pelos órgãos socioassistenciais e são acompanhados por diversos serviços.

No sentido de ser um único serviço, o CASE tem como objetivo contribuir para o desenvolvimento humano ou social dos adolescentes por acreditar que é a partir de suas intervenções com formas de participação e atuação social diferentes das que estão postas, que ocorrerão as transformações na sociedade, conforme consta em seu plano de trabalho e relatórios de gestão anual cujo objetivo é "[...] acompanhar de forma qualificada, contribuindo com seu desenvolvimento pessoal e social, com a ressignificação e apreensão de novos valores, para uma efetiva e produtiva participação na vida social [...]” $(2019$, p.10).

Convergindo com o objetivo do serviço, pode-se considerar que ele segue o disposto na Tipificação Nacional de Serviços Socioassistenciais (2009, p.24), que aponta dentro dos seus objetivos o "acompanhamento social a adolescentes, promoção da inserção em outros serviços e programas socioassistenciais e de políticas públicas setoriais, além de viabilizar condições para a construção/reconstrução de projetos de vida que visem à ruptura com a prática de ato infracional e outros".

Tendo em conta o entrelaçamento acima, cabe destacar que, a proposta deste estudo é analisar as concepções e os significados do processo de escolarização na visão dos sujeitos e a questão central investigada é a compreensão do lugar da escola sobre a ótica deles, os quais, por muitas vezes, são expurgados das instituições enquanto carregam o estigma de "menor infrator", tendo como referencial teórico a pedagogia social e a teoria freireana.

Aqui se faz necessário destacar também que este trabalho, por se tratar de uma pesquisa que se desenvolve na ação cotidiana e no desempenho de ações profissionais, a sua construção é fruto da relação entre sujeito e objeto, ocorrida nesse período de Pandemia da COVID-19, que pode gerar dados expressivos em relação aos impactos desse contexto social na escolarização dos adolescentes.

No que concerne ao cenário de execução das medidas socioeducativas, percorrem nele as questões sociais que podem transformar a vida de todos os cidadãos, por isso, em inúmeros estudos, é veementemente reiterado como indispensável o processo de articulação interinstitucional e intersecretarial, tendo em vista que os adolescentes que cumprem ou cumpriram medida socioeducativa também são usuários de diferentes políticas públicas. Nesse 
sentido, pode contribuir no processo de formulação e implementação de políticas públicas.

Diante disso, foram feitas duas questões que permeiam a proposta deste estudo, sendo elas: 'Qual é a relação entre a medida socioeducativa e a escola?' e 'Qual e como tem sido a sua relação com a escola nesse período da Pandemia da COVID-19?'. Portanto, em posse das verbalizações dos sujeitos no desenvolvimento da entrevista coletiva, esta investigação buscará analisar os discursos para responder às referidas questões e, possivelmente, outras que possam surgir nesse processo metodológico e que estão ligadas com o sistema socioeducativo.

Ainda no que diz respeito às questões e à proposta de coleta de dados, será utilizada a entrevista coletiva, tendo como base de análise a pedagogia social, por olhar as práticas sociopedagógicas, e a teoria freireana, por compreender o ser humano como inconcluso. Nesse sentido, a escolha por esse aporte teórico vem ao encontro de uma resposta plausível no cenário mundial, instalado em decorrência da pandemia, sobretudo o seu impacto nos programas e serviços que executam as medidas socioeducativas em meio aberto.

Salienta-se que o conteúdo desse estudo se encontra num contexto social atual e de cunho relevante para as áreas das ciências humanas e sociais. Nesse sentido, cabe trazer argumentos da pedagogia social espanhola e o seu desenrolar no Brasil, alicerçada na teoria freireana, tendo em vista que é preciso compreender que a PS no Brasil é uma teoria em processo de construção, que possibilita uma discussão do campo prático e teórico, dando aporte aos leitores e a possibilidade de discutir processos de educação voltados para os indivíduos pelos quais a educação formal, historicamente, depositou rótulos e estigmas.

Por fim, o processo de escolarização é aqui analisado de forma crítica, tendo como elemento, presente na medida socioeducativa, o cerceamento da liberdade em contraponto com a educação. Discute-se, por tanto, o lugar que é dado ao adolescente no sistema educativo formal e qual o papel da educação na vida deles. Desponta a ideia de que a exclusão do sistema formal de ensino faz com que um novo processo educativo paralelo tenha de se estabelecer para dar conta das demandas que transcendem a construção de conhecimento propriamente dito, as quais não dão conta de tratá-las como instituições formais de ensino. 


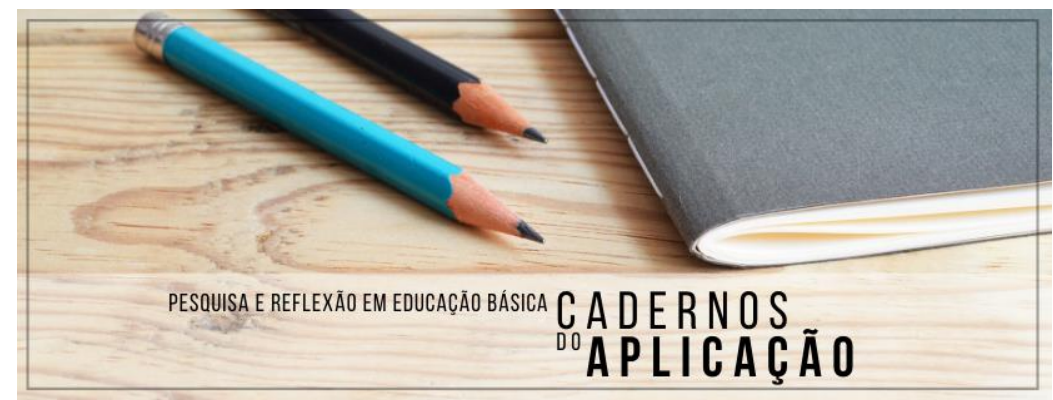

Cadernos do Aplicação https://seer.ufrgs.br/CadernosdoAplicacao Publicação Ahead of Print ISSN 2595-4377 (online) Porto Alegre | jul-dez. 2021 | v.34 | n.2

2 Pandemia, escolarização e medida socioeducativa

No que diz respeito aos procedimentos adotados no processo de execução das medidas socioeducativas em meio aberto no transcorrer da pandemia, em 19 de março de 2020, foi divulgado o Provimento do Conselho Superior de Magistratura $N^{\circ}$ 2546/2020, publicado no Diário da Justiça Eletrônico do Poder Judiciário do Estado de São Paulo (DJE), constando orientações a serem seguidas e, logo em seu artigo primeiro, determinou a suspensão das execuções das medidas socioeducativas pelo prazo de trinta dias, prorrogáveis, se necessário, por conta da pandemia da COVID-19. Entretanto, com o caminhar dos dias, os adolescentes atendidos no CASE passaram a ser contatados por telefone, metodologia essa, focada na perspectiva de manter o vínculo existente entre os educadores, adolescentes e famílias, possibilitando a minimização do impacto desse novo contexto social instalado de forma inesperada.

Diante da persistência do quadro pandêmico, foram editados os comunicados CMS n ${ }^{\circ}$ 47/2020, contado a partir do dia de 16 de abril de 2020; CSM nº 69/2020, a começar no dia de 15 de maio de 2020, e CSM n 91/2020 a contar de 17 de junho de 2020, todos publicados no DJE, prorrogando o prazo do referido artigo, por período igual; a execução tem a previsão para retomar o seu curso normal a partir de 17/07/2020. Posteriormente, em 10 de agosto do corrente ano, os atendimentos aos adolescentes foram retomados, seguindo as orientações de saúde, sendo viabilizadas novas metodologias e práticas no processo de execução, ou seja, com o uso das tecnologias da informação e comunicação têm ocorrido o acompanhamento dos adolescentes de forma presencial e remota, proposta adotada para minimizar e evitar a proliferação da COVID-19.

Diante disso, reitera-se que o percurso desse estudo também respeitou as orientações acima e, sobretudo, tem como proposta descentralizada uma discussão sobre a ruptura do olhar punitivo e sancionatório para a promoção de um processo de responsabilização humanitário. Nesse sentido, perceber a existência da prática de uma ação sociopedagógica emancipatória, que pode proporcionar aos adolescentes a ruptura com o meio ilícito e o (re)direcionamento de sua trajetória de vida, sempre de acordo com as demandas apresentadas por eles próprios, reconhecendo o seu ser e estar no mundo, compreendendo que todos possuem história de vida 
ocorrida antes da prática infracional, auxiliando assim, o processo de desmistificação que percorre esse público.

No que diz respeito à escolarização, no transcorrer da pandemia, percebeu-se que, inicialmente, os adolescentes não demonstravam compreender os novos meios de ensino propostos pela Secretaria de Educação de São Bernardo do Campo, considerando que muitos estudam na modalidade de ensino Educação de Jovens e Adultos - EJA e também Diretoria Regional de Ensino. Todavia, a equipe do CASE apropriou-se das novas orientações metodológicas fornecidas pelas redes de ensino, que propiciaram, como facilitadoras, motivar e sensibilizar os adolescentes para darem continuidade nos estudos, tendo como foco minimizar os impactos da pandemia na vida escolar deles.

Com essa mudança paradigmática em relação à escolarização e o seu impacto na forma de acompanhamento dessa instância dos adolescentes em medida, os educadores cientes da disponibilização remota dos conteúdos escolares, dentre eles, o uso do aplicativo Classroom, aulas televisionadas, materiais didáticos impressos e atividades retiradas na unidade de ensino, estabeleceram constantes contatos telefônicos e chamada de vídeo com os adolescentes, como meio de orientá-los sobre a importância de adaptar-se às novas metodologias disponibilizadas, tendo como meta o fortalecimento do vínculo deles com o processo de escolarização.

Ainda sobre os meios de ensino trazidos pelas redes de educação, constatou-se, inicialmente, nos contatos realizados, uma fragilização dos vínculos entre os adolescentes com as unidades de ensino em que estão matriculados(as), condições essas trazidas por diferentes fatores técnicos, econômicos e sociais. Neste aspecto, citam-se a indisponibilidade de aparelhos eletrônicos e o acesso à internet da população que foi acompanhada nas medidas socioeducativas, a dificuldade de acesso às ferramentas informatizadas, ou seja, aplicativo com uma linguagem que não representa a realidade dos adolescentes, além de outros elementos que contribuíam para o rompimento do vínculo com a escola.

Nessa seara preocupante, tendo como referência a possibilidade real do distanciamento com o processo de escolarização e, consequentemente, o aumento desenfreado de abandono ou evasão escolar, a repetência e, ou, o retrocesso no seu aprendizado, buscou-se, através do diálogo, a sensibilização para o comprometimento com os estudos, tornando possível entender as queixas trazidas pelas famílias em relação à dificuldade do estabelecimento do vínculo 
escolar. Posteriormente, com maior esclarecimento em relação às novas formas de ensino, a equipe de educadores percebeu, nos contatos realizados semanalmente, que os adolescentes, em sua grande maioria, conseguiram uma aproximação com a unidade de ensino, possibilitando, de alguma maneira, a continuidade dos estudos e a entrega das atividades escolares.

Por outro lado, a equipe de educadores do CASE, em contato com diferentes unidades de ensino, puderam constatar que as escolas estão em um movimento de mudança e buscam se aproximar dos alunos de diferentes formas - ligações telefônicas, mensagens trocadas por aplicativo de conversas - whatsapp, envio de e-mail e atendimento nas secretarias escolares, na tentativa de se reinventarem e promoverem a continuidade dos estudos, respeitando as orientações do Ministério da Saúde, demais órgãos e autoridades competentes.

Um dos aspectos importantes desse movimento das redes de educação e do CASE em relação à sensibilização dos estudantes, certamente, corresponde e colabora para que a escola cumpra o seu papel para além do ensino, ou seja, desenvolva a sua função social, reforçando os valores atribuídos à educação destacados nos documentos norteadores, como a Constituição Federal, a Lei de Diretrizes e Bases da Educação Nacional (LDB), Plano Nacional de Educação e a Base Nacional Comum Curricular (BNCC).

Ainda dentro deste conceito de função social, pode ser destacado que o papel das medidas socioeducativas e da educação, especialmente nesse momento de crise sanitária, econômica e social, são de suma importância para a concretização dos direitos humanos e da proteção integral das crianças e dos adolescentes que, alicerçados aos princípios da alteridade, empatia e solitude, podem viabilizar excelentes resultados e a minimização dos impactos trazidos pela COVID-19 à sociedade.

No entanto, há de se salientar que, ainda que a barreira tecnológica tenha sido resolvida ou minimizada, existem outros problemas no processo de escolarização, levando em consideração que a crise do coronavírus apresenta uma situação de mudança de hábito imediata e, certamente, terá efeitos perenes sobre a forma de aprender, bem como as formas de retorno às atividades escolares presenciais. 


\section{Proteção integral: da pedagogia social espanhola à educação popular}

É inegável que o berço da educação social e da pedagogia social (PS) é a Alemanha, reconhecendo a organização social, a elaboração de terminologias e a fundamentação teórica da área. Cabanas (1997, p. 77), relata que os estudiosos alemães atrelam a aparição da pedagogia social a um campo prático para responder aos inúmeros problemas sociais causados no decorrer do processo desenfreado de industrialização, tais como as constantes imigrações, greves, aglomerações urbanas, aumento dos bairros periféricos e outras questões que desestruturam a vida humana, e que a educação social pode atuar enquanto ação para solucionar e/ou minimizar essas vulnerabilidades sociais.

Dissertando sobre o processo de construção histórica de estruturação da PS, Cabanas (1997, p. 78), salienta que ocorreram grandes movimentos pedagógicos no período Weimar, especificamente, as escolas direcionadas para o preparo dos jovens para o ingresso no mundo do trabalho e as universidades populares. Entretanto, com o período pós-guerra também surgiu a questão da delinquência juvenil, ocorrendo o estabelecimento de leis e instituições para controlar essa nova realidade. Diante disso, tornou-se essencial a construção e o fortalecimento da ideia de uma pedagogia social que respondesse de forma assertiva esse novo cenário vivenciado, surgindo também em 1922 a promulgação da lei de proteção aos jovens em situação de risco, além da criação dos serviços de assistência à juventude e às crianças.

Passando para o contexto espanhol, Cabanas (1997, p. 89) destaca que a Espanha passou a buscar compreender e estudar a PS no século XX. Nesse período, a pedagogia espanhola já apontava convergências com a pedagogia alemã. Segundo López (2009, p. 97), no ano de 1915, María de Maeztu (1882-1948) traduziu do alemão para o espanhol a obra de Paul Nartop, intitulada de Pedagogía Social: teoría de la educación de la voluntad.

Paul Natorp (1913), em sua obra Pedagogía Social: teoría de la educación de la voluntad, traduzida e considerada como um marco sobre a importância da PS, traz em sua fundamentação filosófica grande relevância para compreensão da PS, servindo de estímulo para que novas produções acadêmicas surgissem, além de orientar a formação profissional da área. Ele transcende o seu tempo e constrói um conceito plausível que enfatiza a ideia de que a educação dos indivíduos está condicionada socialmente às condições socioculturais e sociais, 
Cadernos do Aplicação

https://seer.ufrgs.br/CadernosdoAplicacao

Publicação Ahead of Print

ISSN 2595-4377 (online)

PESQUisa e REFLEXão em EdUCAÇão básica C A DE R N OS

concluindo que "[...] a Pedagogia Social não é a educação do indivíduo isolado, mas sim do homem que vive em uma comunidade, porque a sua finalidade não é somente o indivíduo". (NATORP, 1913, p. 97).

No que tange ao conceito da educação apresentado por Nartop, Carreras (1997, p. 43), enfatiza que ele desaprovava veemente a ideia de educação enquanto uma perspectiva “individualista", predominante em sua época, reforçando o processo educacional como um importante fenômeno social. Morente (apud CARRERAS, 1997, p. 44), intérprete kantiano de Natorp, traz o conceito de educação como uma extensão da comunidade quando destaca que “[...] la educación es, para Natorp, educación para la comunidad”. Nesse sentido, pode-se considerar que a partir da perspectiva da pedagogia social desenvolvida na Espanha, se entende a educação não formal como um "conjunto de processos, meios, instituições, específica e diferencialmente desenhados em função de explícitos objetivos de formação e instrução que não estão diretamente dirigidos à concessão de grau próprio do sistema educativo formal" (TRILLA, 1996, p. 30).

Essa definição trazida por Natorp, sem dúvida, pode ser um dos primeiros apontamentos de ligação com a concepção de Paulo Freire de educação, sendo o elo de ligação o pressuposto de que “[...] ninguém educa ninguém, como tampouco ninguém se educa a si mesmo: os homens se educam em comunhão, mediatizados pelo mundo". (FREIRE, 1987, p. 79). Nesse contexto, pode-se identificar a semelhança na fundamentação da educação popular freireana com a concepção de Natorp, considerado o pai da pedagogia social.

Segundo Carreras (1997, p. 42), a gênese da pedagogia social foi influenciada teoricamente pelas concepções de educação trazidas por Kant e Hegel. Descreve que a construção do conceito de pedagogia social feito por Natorp obteve grande inspiração no idealismo kantiano, tendo em vista o argumento feito: "[...] a realidade social existe na ideia antes que nas ações concretas [...]" (CARRERAS, 1997, p. 44), e a pedagogia social é sustentada pela perspectiva hermenêutica de Hegel. Esse conceito recebeu também contribuições de várias correntes e autores, dentre eles Platão, Hegel, Kant e Pestalozzi.

Diante da relação direta da Espanha com os princípios da PS alemã, ela passou a influenciar também outros países, como é o caso do Brasil. Nesse sentido, no cenário brasileiro, podem-se apontar algumas aproximações do legado freireano com os pressupostos trazidos pela 
pedagogia social alemã e espanhola, trazendo algumas definições, conceitos e práticas que podem estar ligados à pedagogia social, educação social, educação popular e outras denominações, presentes em nosso cotidiano.

Na história da educação brasileira, um dos documentos importantes é o manifesto dos Pioneiros da Educação, de 1932, em que são identificadas algumas inspirações as quais apontam para a necessidade de uma organização escolar que seja verdadeiramente inclusiva, atendendo às demandas dos diversos grupos existentes na sociedade. Os teóricos que participaram na construção desse documento não são considerados fundadores de uma PS, porém o processo de lutas que permeou aquela época norteia um entendimento para a inclusão de práticas educativas que vislumbram a transformação, a conscientização e a emancipação, presentes na teoria freireana.

No Brasil, na década de 1990, iniciava-se a discussão em relação à teoria e às metodologias no campo de conhecimento da pedagogia social, tendo entre os principais precursores grandes referências da educação, assistência social e direitos humanos, tais como: Antônio Carlos Gomes da Costa, trazendo importantes contribuições científicas em relação às metodologias e tecnologias para a educação social ("Brasil criança urgente”, 1994; Pedagogia da presença, 1997), disseminadas pelo Instituto Brasileiro de Pedagogia Social; Maria Stela Graciani ("Pedagogia Social de Rua", 1997); e Caliman, com sua exímia pesquisa ("Desafios, riscos desvios", 1998), realizada com os adolescentes trabalhadores no Brasil e na Itália (“Normalità devianza lavoro", 1995). (Cf. SOUZA NETO et al., 2009).

Diante disso, a pedagogia social passa a ser compreendida como uma "[...] ciência pedagógica da inadaptação social [...] da educação para a paz, da educação cívica e política, sobre ação educativa nos serviços sociais, da marginalização social e dos meios de comunicação social" (MACHADO, 2013 apud SOUZA NETO et al., 2009, p. 138). Sendo assim, pode ser compreendida como uma ciência para a promoção de uma educação voltada para a democracia, a liberdade e a igualdade, reconhecendo a importância de todos em seu processo de implementação e concretização, podendo aqui ser considerado o aceno à teoria freireana.

Mollenhauer, conhecido por seus estudos e defesa da pedagogia social crítica, propõe mudanças sociais e a busca pela interface entre educação e estrutura social (PÉREZ SERRANO, 2004, p. 49), e enfatiza a centralidade na transformação da realidade social e a conscientização 
do ser humano em relação ao desempenho de seu papel social no mundo.

Paulo Freire, com a sua prática, conseguiu influenciar o estilo de fazer educação social no Brasil. Sendo assim, para refletir sobre essa perspectiva da PS crítica de Mollenhauer no contexto brasileiro, deve-se considerar que Paulo Freire também vislumbrava a educação social como uma orientação à mudança social, especificamente uma proposta de conscientização e "emancipação" dos "oprimidos", para que todos consigam fazer uma leitura de mundo e não reproduzam as situações de opressão que podem ter sido vivenciadas (FREIRE, 1987). Diante disso, o autor afirma que o diálogo é o caminho para a conscientização, nesse sentido, pode-se estabelecer relação com o processo de responsabilização pedagógica existente na medida socioeducativa.

Para Silva (2012), a educação social e a pedagogia social não são sinônimos, não são dicotômicas, nem mesmo contraditórias, considerando que a PS deve ser considerada como um campo teórico o qual designa as práticas socioeducativas, permeadas pela educação social, tendo como premissa as diversas nuances, contextos e campos de atuação dos educadores sociais e de outros profissionais que atuam na promoção, garantia e efetivação dos direitos. Contudo, enfatiza a existência e a relevância dos quatro campos de domínio, dentre eles o domínio sociopedagógico que tem como áreas de conhecimento a infância, adolescência, juventude e terceira idade e a sua prática tem como objetivo o desenvolvimento de habilidades e competências sociais que permitam às pessoas a ruptura e superação das condições de marginalidade (SILVA, 2012, p. 155-178).

Mediante os conceitos trazidos pela pedagogia social para o Brasil e, levando em consideração o domínio citado, pode-se destacar que se ancoram na educação popular, conforme destacado anteriormente ao descrever a teoria freireana. Nessa perspectiva, pode-se salientar que é no contexto socioeducativo que ela se alinha com as propostas trazidas pela socioeducação ao transcender a relação ensino-aprendizagem, incorporar novos elementos e valores que corroboram com o rompimento do aspecto sancionatório deixado pelo legado da situação irregular. Entretanto, essa junção da pedagogia social e teoria freireana na medida socioeducativa materializa a Doutrina da Proteção Integral, reconhecendo os adolescentes enquanto sujeitos de direitos e protagonistas de sua própria história, processo esse que o educador pensa com o adolescente e não por ele. 


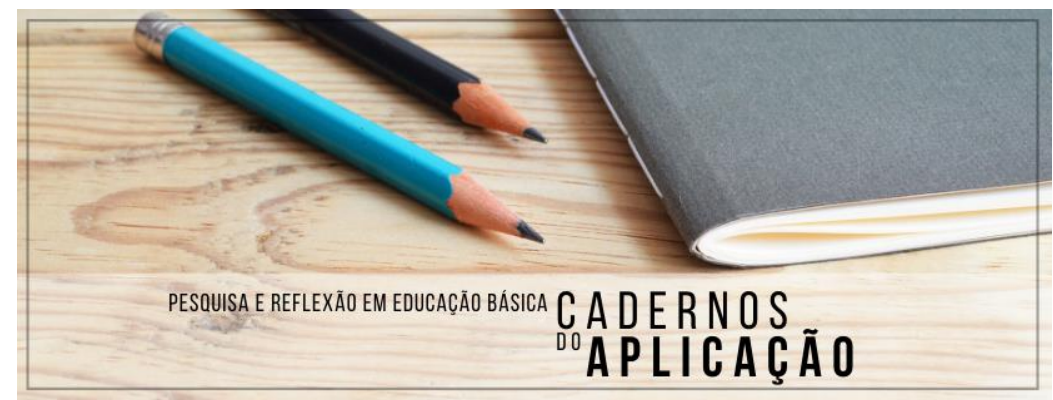

Cadernos do Aplicação

https://seer.ufrgs.br/CadernosdoAplicacao

Publicação Ahead of Print

ISSN 2595-4377 (online)

Porto Alegre | jul-dez. 2021 | v.34 | n.2

\section{Entrevista coletiva}

Os adolescentes escolhidos para a pesquisa fazem parte do contingente de atendidos pelo CASE e, em julho do corrente ano, data de execução da entrevista coletiva, encontravamse no penúltimo mês de cumprimento da medida socioeducativa de liberdade assistida, bem como se disponibilizaram para participar do estudo, sendo todos esclarecidos sobre o sigilo de sua identidade, possibilitando cada um escolher o nome fictício para conter no estudo, apenas sendo pedido para que escolhessem um "apelido", levando em consideração o que estavam sentindo nesse momento de pandemia.

Diante da escolha do referido do instrumento para coleta de dados, foram convidados nove adolescentes, estes já adaptados a metodologia de atendimento via plataformas digitais, respeitando o distanciamento social, adotado pela equipe do CASE. No entanto, antes de ser realizada a entrevista coletiva, um dos adolescentes, no dia que antecedeu a realização dela, reincidiu na prática de ato infracional equiparada a tráfico de drogas e recebeu nova medida socioeducativa, condizente em restrição da liberdade em estabelecimento educacional, desde então, encontra-se custodiado em uma unidade da Fundação CASA.

No início da entrevista, ocorrido de forma remota e que durou 01h40min, foi informado o objetivo e a importância da contribuição voluntária, dando ênfase de que não apresenta nenhuma interface positiva/negativa na medida socioeducativa que cumprem e, destacado, que os resultados podem contribuir para o aprimoramento da política socioeducativa e da educação, tendo como proposta a disseminação de conhecimentos e o surgimento de novas abordagens sobre esse tema. Desta forma, abaixo consta uma tabela com detalhes dos participantes desse estudo. 
Quadro 1 - Características e descrição prévia dos sujeitos da pesquisa

\begin{tabular}{|c|c|c|c|c|c|c|}
\hline $\begin{array}{c}\text { NOME } \\
\text { ADOTADO }\end{array}$ & IDADE & SEXO & $\begin{array}{l}\text { INTEGRANTES } \\
\text { NA FAMÍLIA }\end{array}$ & $\begin{array}{c}\text { RENDA } \\
\text { FAMILIAR } \\
\text { PER } \\
\text { CAPITA }\end{array}$ & $\begin{array}{l}\text { AUTODECLARAÇÃO } \\
\text { COR /RAÇA }\end{array}$ & $\begin{array}{c}\text { ATO } \\
\text { INFRACIONAL } \\
\text { QUE } \\
\text { CULMINOU NA } \\
\text { MEDIDA }\end{array}$ \\
\hline NOVIN & 15 & $\mathrm{M}$ & 05 & $\mathrm{R} \$ 700,00$ & BRANCA & ROUBO \\
\hline PARÇA & 15 & M & 05 & $\mathrm{R} \$ 320,00$ & PARDA & ROUBO \\
\hline PAULO & 16 & $\mathrm{M}$ & 07 & $\mathrm{R} \$ 78,57$ & BRANCA & $\begin{array}{c}\text { TRÁFICO DE } \\
\text { DROGAS }\end{array}$ \\
\hline MENOR & 16 & $\mathrm{M}$ & 05 & $\mathrm{R} \$ 452,00$ & PARDA & $\begin{array}{c}\text { TRÁFICO DE } \\
\text { DROGAS }\end{array}$ \\
\hline PAZ & 17 & $\mathrm{M}$ & 06 & $\mathrm{R} \$ 585,00$ & NEGRA & $\begin{array}{l}\text { TRÁFICO DE } \\
\text { DROGAS }\end{array}$ \\
\hline DENIS & 17 & M & 02 & $\mathrm{R} \$ 715,00$ & PARDA & ROUBO \\
\hline MC & 18 & $\mathrm{M}$ & 05 & $\mathrm{R} \$ 220,00$ & NEGRA & FURTO \\
\hline BEL & 18 & $\mathrm{~F}$ & 06 & $\mathrm{R} \$ 209,00$ & BRANCA & $\begin{array}{c}\text { LESÃO } \\
\text { CORPORAL }\end{array}$ \\
\hline
\end{tabular}

Fonte: Elaborado pelos autores.

Ressalta-se que a participação nesta pesquisa não se confundiu com as ações de acompanhamento que estão recebendo no decorrer do cumprimento da medida socioeducativa. Sendo assim, a entrevista coletiva constitui-se em uma participação voluntária, inexistindo qualquer bônus e/ou ônus em relação ao processo socioeducativo em curso. Sendo assim, podemos citar que um dos aspectos importantes e pertinentes para o desenrolar do objetivo central deste estudo, além de viabilizar a obtenção de dados fidedignos, foi a escolha de adolescentes residentes nas regiões com maior índice de violência e vulnerabilidades sociais, conforme Índice Paulista de Vulnerabilidade Social (IPVS-2010). Esse índice registra indicadores socioeconômicos, escolarização dos adolescentes e jovens de 15 a 29 anos e proporção de habitantes na mesma faixa etária, divididos por região.

Outro aspecto em relação a característica do instrumento científico para obtenção de dados é o diálogo, na qual se explica o mundo por meio do discurso dos homens, sustenta a estratégia adotada na pesquisa de campo, que leva em consideração o trinômio ação-reflexão- 
ação ${ }^{4}$, que é um dos princípios da ação sociopedagógica realizada no transcorrer da execução das medidas socioeducativas em meio aberto, dando-lhe o caráter pedagógico.

No que se refere à estratégia adotada, foram escolhidas duas categorias de análises, tomadas como referência à teoria freireana. A primeira em que se ancorou foi a ação/reflexão, em busca da compreensão do modo como os adolescentes agem no mundo e em que medida as suas ações são permeadas pelo pensamento crítico; a segunda conscientização/responsabilização, categoria que permite compreender o senso crítico e aprofundar a discussão sobre as regras socialmente estabelecidas, seu sentimento de pertencimento à sociedade, a escola e a família, e em que medida se sente responsável pelos atos ilícitos cometidos, ou atribui a terceiros a "culpa" de sua condição.

Como passo metodológico e de valor imensurável, foram transcritas integralmente as respostas das questões abordadas na entrevista coletiva e, posteriormente, analisadas de forma sistemática as afirmações feitas, sua frequência, ênfase, concepções e até os significados para os envolvidos, extraindo o máximo de informações que possam responder, por meio do ponto de vista dos sujeitos da pesquisa, aos desafios e às perspectivas da relação entre medida socioeducativa e escolarização.

Bourdieu (1999), aponta que a transcrição de entrevista não é só aquele ato mecânico de passar para o papel o discurso gravado pois, de alguma forma o pesquisador tem que apresentar os silêncios e, até mesmo, os ruídos na comunicação, os gestos, os risos, a entonação de voz do informante durante a entrevista. O pesquisador tem o dever de ser fiel, ter fidelidade quando transcrever tudo o que o pesquisado falou e sentiu durante a entrevista.

No transcorrer da análise dos dados obtidos, vislumbra-se transcender, com maior profundidade, o aparente, e qualificar o diálogo a ponto de atingir os objetivos desta investigação proposta, para que, após a conclusão do estudo de campo e em posse dos dados obtidos, se realize uma análise qualitativa crítica e se tracem os pontos de vista levantados ao longo da entrevista coletiva e, assim, sejam descritos com veracidade a concepção e os significados das ações sociopedagógicas para os adolescentes.

Por fim, materializa-se essa investigação, conforme os quadros a seguir, tendo como elemento fundante compreender de forma macro as verbalizações proferidas pelos sujeitos que

\footnotetext{
${ }^{4}$ Sobre esse tema, ver Freire (1987) e Freire (2001).
} 
Cadernos do Aplicação https://seer.ufrgs.br/CadernosdoAplicacao Publicação Ahead of Print ISSN 2595-4377 (online)

se disponibilizaram a participar deste estudo, a partir da análise da concepção e dos significados em relação à temática deste estudo, atribuídos por eles, bem como explorar os seus pontos de vista, os valores expressos em suas opiniões, o modo como defendem os seus pontos de vista, a interação com os demais participantes e as respostas dadas às duas questões realizadas.

Quadro 2 - Dados educacionais dos sujeitos da pesquisa

\begin{tabular}{|c|c|c|c|c|}
\hline $\begin{array}{c}\text { NOME } \\
\text { ADOTADO }\end{array}$ & ESCOLARIDADE & $\begin{array}{c}\text { MATRICULADO } \\
\text { ANTES DO INÍCIO } \\
\text { DA MSE }\end{array}$ & $\begin{array}{l}\text { RETORNO AOS ESTUDOS } \\
\text { DURANTE A MEDIDA }\end{array}$ & $\begin{array}{l}\text { MAIOR TEMPO QUE } \\
\text { ESTEVE FORA DA } \\
\text { REDE DE ENSINO }\end{array}$ \\
\hline NOVIN & $\begin{array}{c}1^{\circ} \text { ENSINO } \\
\text { MÉDIO }\end{array}$ & SIM & --- & -- \\
\hline PARÇA & $\begin{array}{c}8^{\mathrm{a}} \text { ENSINO } \\
\text { FUNDAMENTAL }\end{array}$ & $\mathrm{NÃO}$ & SIM & 6 MESES \\
\hline PAULO & $\begin{array}{c}6^{\mathrm{a}} \text { ENSINO } \\
\text { FUNDAMENTAL }\end{array}$ & SIM & & 2 ANOS \\
\hline MENOR & $\begin{array}{c}8^{\mathrm{a}} \text { ENSINO } \\
\text { FUNDAMENTAL }\end{array}$ & $\mathrm{NÃO}$ & SIM & $1 \mathrm{ANO}$ \\
\hline PAZ & $\begin{array}{c}8^{\mathrm{a}} \text { ENSINO } \\
\text { FUNDAMENTAL }\end{array}$ & $\mathrm{NÃO}$ & SIM & 8 MESES \\
\hline DENIS & $\begin{array}{c}5^{\mathrm{a}} \text { ENSINO } \\
\text { FUNDAMENTAL }\end{array}$ & $\mathrm{NÃO}$ & SIM & 4 ANOS \\
\hline MC & $\begin{array}{l}1^{\circ} \text { ENSINO } \\
\text { MÉDIO }\end{array}$ & SIM & --- & $1 \mathrm{ANO}$ \\
\hline BEL & $\begin{array}{l}1^{\circ} \text { ENSINO } \\
\text { MÉDIO }\end{array}$ & $\mathrm{NÃO}$ & SIM & $1 \mathrm{ANO}$ \\
\hline
\end{tabular}

Fonte: Elaborado pelos autores. 


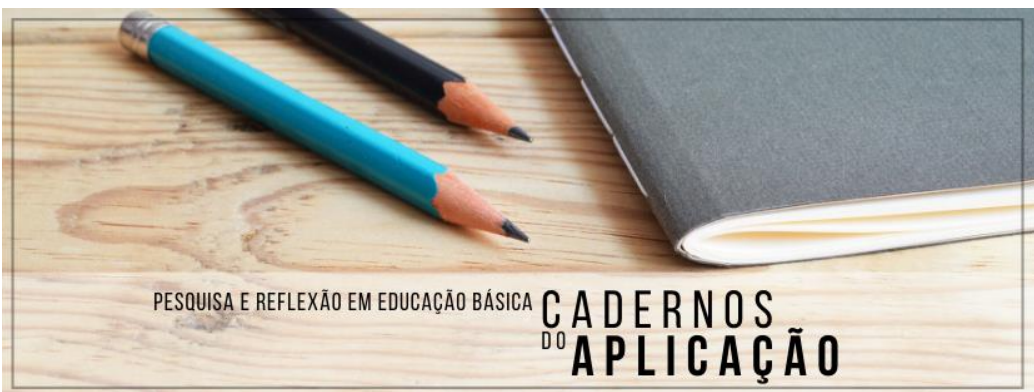

Cadernos do Aplicação

https://seer.ufrgs.br/CadernosdoAplicacao

Publicação Ahead of Print

ISSN 2595-4377 (online)

Porto Alegre | jul-dez. 2021 | v.34 | n.2

\section{Quadro 3 - Dados educacionais dos sujeitos da pesquisa}

\begin{tabular}{|c|c|}
\hline \multicolumn{2}{|r|}{$\begin{array}{l}\text { Qual é a relação entre a medida e a escola? } \\
\text { Qual e como tem sido a sua relação com a escola nesse período da pandemia da COVID-19? }\end{array}$} \\
\hline SUJEITOS & PRINCIPAIS VERBALIZAÇÕES \\
\hline NOVIN & $\begin{array}{l}\text { - Diferente em tudo. Na escola, aprende que vamos se educar no ensino, através do que } \\
\text { vai usar no mundo. Aqui, com os educadores, se fala de forma ampla em tudo, mais claro, } \\
\text { trocando ideias para nossa melhora. } \\
\text { - Esse negócio de pandemia só me afastou mais da escola, estou indo buscar materiais e } \\
\text { tento, às vezes, fazer as atividades, muito "moiado" essa fita de fazer as coisas da escola } \\
\text { aqui em casa. }\end{array}$ \\
\hline PARÇA & $\begin{array}{l}\text { - Aqui aprendi pra "caralho", sem julgamento, a roda pra trocar ideia me ajudou ficar mais } \\
\text { de boa e aprendi o sentido de muita coisa na minha caminhada. Na escola, tem só que } \\
\text { passar, aquelas coisas que eu nem sei por quê. } \\
\text { - Não sei nada dessa pandemia, sobre a escola na pandemia piorou, tô no whatsapp e vejo } \\
\text { várias mensagens e atividades que nem dá pra tentar e conseguir fazer, fico só olhando } \\
\text { mesmo. }\end{array}$ \\
\hline PAULO & $\begin{array}{l}\text { - Certas situações sim, quando falam de leis. Eu vejo que terminar escola é só o começo. } \\
\text { Hoje, a maioria dos serviços pede o ensino médio. } \\
\text {-A escola já sem a pandemia era complicado, agora virou um lugar deserto e só tem acesso } \\
\text { os donos do ouro. }\end{array}$ \\
\hline MENOR & $\begin{array}{l}\text { - Falam de bastante coisa que a medida socioeducativa fala, tem o mesmo papel de } \\
\text { educador. Na escola, falam pouco dos nossos direitos, parece que têm medo. Aqui na } \\
\text { medida tem liberdade, vou falar e vão entender, tem liberdade. Na escola, não querem } \\
\text { saber se passamos na Fundação CASA, lá somos números. Ensino médio hoje em dia é } \\
\text { "prézinho" para ganhar "mil conto". } \\
\text { •Estou na rua nessa pandemia, escola nem se fala e o pessoal da escola não está nem aí se } \\
\text { eu vejo ou não as atividades. }\end{array}$ \\
\hline PAZ & $\begin{array}{l}\text { - Uma coisa não tem nada com a outra. Na escola, tem lição, não discute sobre família e } \\
\text { um monte de coisa que aqui na medida podemos falar e agora se estivesse um amigo meu } \\
\text { aqui eu iria falar com ele de bicicleta, porque sentimos felicidade e cansaço quando } \\
\text { andamos de bicicleta, até fazendo o barulho de moto "Bruuuuuuu". Aqui na medida fala } \\
\text { também da educação e na escola também, por isso sou educado com quem é educado } \\
\text { comigo. Não faço bagunça na escola, nunca nem falei pra ninguém direito que eu cumpro } \\
\text { L.A. Se alguém falasse que eu cumpro e fosse meu amigo, até que beleza, ruim se quem } \\
\text { falasse não fosse meu amigo porque eu já ia logo perguntar pra pessoa porque ela está } \\
\text { cuidando da minha vida. } \\
\text {-A escola não sabe nem dos alunos normais e já imagina nós "menor infrator" da medida } \\
\text { que já não ligam o ano todo, agora já era o ano. }\end{array}$ \\
\hline DENIS & $\begin{array}{l}\text { - Muito diferente, né, senhor? Lá na escola, aprende mais, né? Aprende a ler e escrever, e } \\
\text { aqui aprendemos da caminhada da vida. Mesmo assim, acho que aqui aprendi mais, mesmo } \\
\text { assim, dou mais valor na vida depois das conversas. Já parei de estudar e estou na quinta } \\
\text { série [risos]. Acho que todas as vezes que entrei para o crime não me importei com a } \\
\text { escola. Agora, vou seguir na caminhada, senhor. Essa já é a terceira vez que tô assinando } \\
\text { e vou ficar suave na vida, "seguir na caminhada de boa", sem pensar muito no que podem } \\
\text { estar pensando de mim, só ficar tranquilo. Quero mesmo é ir agora para Paraíba visitar } \\
\text { meus coroas (avós) porque eles cuidaram de mim por muito tempo, até } 14 \text { anos, e já estão } \\
\text { velhos demais. Preciso dar atenção que eles merecem. Minha avó, por exemplo, já vai }\end{array}$ \\
\hline
\end{tabular}




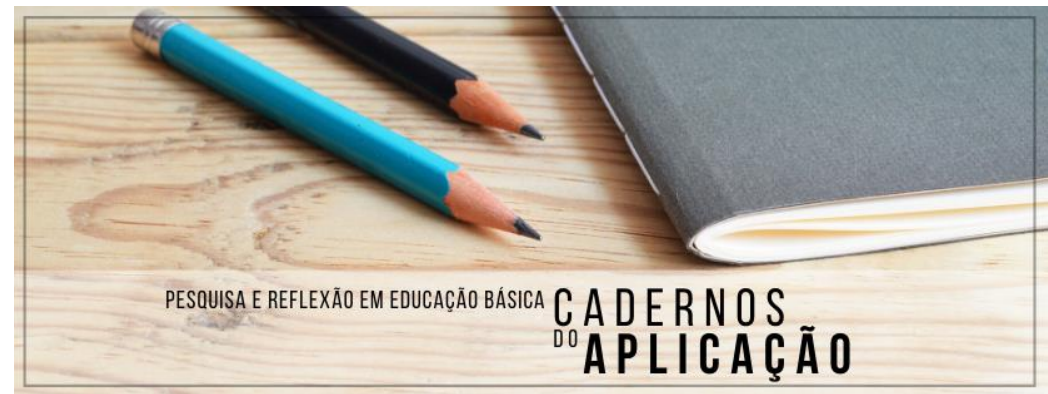

Cadernos do Aplicação

https://seer.ufrgs.br/CadernosdoAplicacao

Publicação Ahead of Print

ISSN 2595-4377 (online)

Porto Alegre | jul-dez. 2021 | v.34 | n.2

\begin{tabular}{|c|c|}
\hline & $\begin{array}{l}\text { fazer } 90 \text { anos, e isso já fica difícil de viver. Ainda bem que ela chegou nesse ano, porque } \\
\text { nós aqui nem podemos chegar nessa idade com a caminhada errada, por isso vou ir visitar } \\
\text { eles até pra conseguir agradecer por tudo, né, senhor? Quem agradece já reconhece o corre } \\
\text { que o outro fez por nós, assim que a vida circula atrás de qualquer coisa. } \\
\text { - Acho a escola um luxo para quem tem acesso a computador e internet, estou tranquilo, } \\
\text { depois que passar essa fita de coronavirus eu vejo o que fazer na escola. }\end{array}$ \\
\hline MC & $\begin{array}{l}\text { - Não, o que eu aprendo na escola é lição e aqui eu aprendi a convivência. Posso dar como } \\
\text { exemplo aqui "parças", que aqui podemos sair para alguns lugares e conhecer outras } \\
\text { coisas, outras realidades, fiz alguns amigos. No início até achei quando cheguei que eu era } \\
\text { diferente dos outros adolescentes e, no passar do tempo, dá pra perceber que todos aqui } \\
\text { somos iguais, só a diferença é a forma de educação que receberam em casa, por exemplo: } \\
\text { alguns falam bastante palavrão, e eu já não sou muito de falar. Só isso que muda mesmo, } \\
\text { porque somos iguais na mesma situação. } \\
\text {-A escola só usou a pandemia como um pano para não me ajudar e não ajudar os "menor" } \\
\text { que dá trabalho, tipo nós, agora fico sem mais um problema na escola e eles não querem } \\
\text { se comunicar com problema, vamos ver quando isso de pandemia acabar. }\end{array}$ \\
\hline BEL & $\begin{array}{l}\text { - Não tem nada a ver, porque o que ensina na escola a gente nem presta atenção, pra ser } \\
\text { sincera. Aí aqui nós já fica mais de boa, porque aqui as pessoas que nós convive é tipo da } \\
\text { mesma personalidade que a gente. Têm umas pessoas que não sabem explicar certas coisas } \\
\text { lá na escola. Acho que, na escola, se todos soubessem que eu sou de medida, iriam me } \\
\text { julgar e não me passar o conhecimento, nem me ensinar direito igual ensinam as outras } \\
\text { pessoas. Iam olhar para o que eu fiz e não quem eu sou, tipo, julgar mesmo. } \\
\text { •Não sei de nada, acho que essa pandemia acabou com o ano e agora a escola já lavou as } \\
\text { mãos, se eu for lá beleza e se eu não for pra eles também beleza, sei lá vamos ver o que } \\
\text { vai rolar né }\end{array}$ \\
\hline
\end{tabular}

Fonte: Elaborado pelos autores.

\section{Análise dos dados}

Até aqui é sabido que a educação brasileira carrega em seu legado as marcas deixadas pelo período do Brasil colonial. Dentre elas, pode-se destacar a seletividade que desenhou uma tatuagem no processo educacional quando desconsiderou o contexto histórico, social, cultural e econômico desfavorável na maioria da população e ocasionou a proliferação da exclusão escolar.

No universo em que estão inseridos os adolescentes em conflito com a lei, a exclusão escolar pode ser constatada de forma acentuada quando, no decorrer das questões respondidas na entrevista coletiva, percebe-se nos discursos que eles não reconhecem a escola enquanto um espaço educacional, protetivo e de inclusão social, concepção essa alarmante e que pode ser um dos aspectos que contribui para o aumento da evasão estudantil, além de não trabalhar em prol da diminuição da reincidência infracional e o próprio rompimento com o meio ilícito. 
Em detrimento do contexto exposto acima, podemos buscar uma resposta plausível nos objetivos empregados na Tipificação Nacional de Serviços Socioassistenciais (2009) e nas orientações técnicas preconizadas no Sistema Nacional de Atendimento Socioeducativo SINASE (2006), quando aponta que, dentre as ações, realizadas na execução das medidas socioeducativas, é essencial o acompanhamento escolar, respeitando as singularidades e especificidades de cada um e da rede de ensino, levando em consideração que o conhecimento é um instrumento de transformação social e que pode proporcionar elementos para que os adolescentes tenham embasamento para conseguir romper com as barreiras impostas por esse processo de exclusão.

Todavia, possivelmente, se relacionarmos os adolescentes em cumprimento de medida socioeducativa com o processo de exclusão escolar, tendo como base as dificuldades deles em responder as questões deste estudo e, por vezes, a superficialidade nas respostas, além dos rótulos que lhes são impostos e a forma de tratamento que recebem em diversos equipamentos públicos, o referido processo contribui para que eles sejam estigmatizados, além de se ausentar.

No desenrolar do processo socioeducativo, especificamente nesse contexto social de pandemia instalada, é mais do que necessário pensar uma educação dialógica, novas propostas de abordagens e metodologias educacionais que reconheçam o contexto situacional dos sujeitos e, nessa seara, identificar que as ações e reações ocorridas na escola podem estar diretamente influenciadas pelo contex to em que os alunos vivem.

Outro aspecto importante no âmbito escolar, constatado logo na caracterização dos sujeitos da pesquisa, é a importância do acolhimento e/ou recepção escolar dada aos adolescentes envolvidos ou que estiveram envolvidos com o meio ilícito, uma vez que a maioria, no decorrer de sua trajetória educacional, já rompeu por algum período a sua relação com a escola. Nessa perspectiva, no transcorrer da medida socioeducativa, os adolescentes são orientados e acompanhado o seu processo de escolarização, por isso, ao retornarem para a instituição escolar, precisam ser estimulados a sentir, reconhecer e pertencer ao universo educacional. Dessa forma, a existência e eficácia de ações setoriais e interinstitucionais deveriam ocorrer de forma contínua, para estreitar a relação entre a assistência social, judiciário e o sistema educacional, a fim de inexistir qualquer tratamento diferenciado e/ou ação discriminatória. 


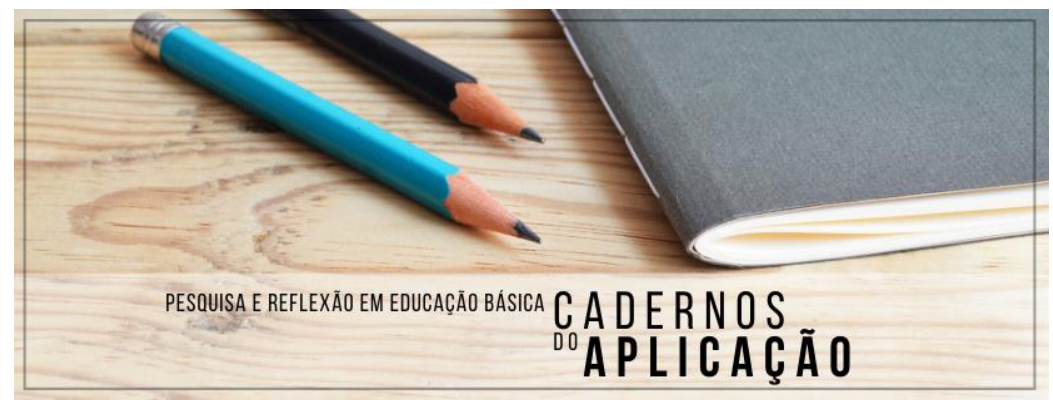

Cadernos do Aplicação

https://seer.ufrgs.br/CadernosdoAplicacao

Publicação Ahead of Print

ISSN 2595-4377 (online)

Porto Alegre | jul-dez. 2021 | v.34 | n.2

Um dos pontos que podem ser observados no desenrolar da entrevista coletiva, mesmo que de forma intrínseca nas colocações, é que as relações educacionais, muitas vezes, desconsideram os seus saberes, transformam o processo escolar numa zona afastada e inalcançável, exploram as limitações e desfavorecem o percurso pedagógico educativo. Nesse caso, ampliam esse olhar discriminatório quando o adolescente apresenta em sua trajetória escolar, reprovações, evasão e/ou distorção idade-série, acentuando esse processo excludente, quando constatado que o adolescente cumpre medidas socioeducativas.

No que tange a como os entrevistados notam a escola e como acreditam serem reconhecidos nela, quase na integralidade dos discursos proferidos, constatou-se que ela, por vezes, é vista como um espaço importante para formação e que em algum momento da vida terão que se dedicar a ela, porém, em outro momento é compreendida como fora da realidade deles, omissa, repressora e, muitas vezes, discriminatória. Eles apresentam impressões de como acreditam serem vistos, utilizando os termos "problema" e "menor infrator", entre eles e os procedimentos escolares, colocações essas que possivelmente podem culminar em aumento da evasão escolar.

A escola, portanto, se consideradas as respostas das duas questões desse estudo, não é reconhecida enquanto uma instituição de proteção social e desenvolvimento, além disso, pode ser compreendida como um espaço que desresponsabiliza-se pelo processo paulatino de discriminação dos adolescentes em conflito com a lei, sendo vista como uma ilha de poucas perspectivas, fechada para o novo, para a possibilidade de escuta e acolhida e, principalmente, impermeável ao potencial daqueles que fogem do padrão disciplinar exigido. Nesse entendimento, pode-se considerar as palavras por Paulo e Denis, quando questionados sobre a escola em tempo de pandemia:

A escola já sem a pandemia era complicado, agora virou um lugar deserto e só tem acesso os donos do ouro. (Paulo)

Acho a escola um luxo para quem tem acesso a computador e internet, estou tranquilo, depois que passar essa fita de coronavirus eu vejo o que fazer na escola. (Denis)

Nesse contexto, pode-se afirmar que a necessidade de trocar as lentes para conhecer novos horizontes, construir novas pontes e romper essa visão distorcida de educação, nesse novo ciclo, reforça a reflexão freireana de que "só existe saber na invenção, na reinvenção, na 
busca inquieta, impaciente, permanente, que os homens fazem no mundo, com o mundo e com os outros." (FREIRE, 1987, p. 68-69).

Assim como o acompanhamento pelo qual passa em função da medida socioeducativa, a escola surge nos discursos, mesmo que de forma intrínseca, como obrigatoriedade, dando a impressão de se confundir com um mesmo processo punitivo no qual o opressor é difuso, representado por diferentes instituições, cabendo ao adolescente, em seu lugar de oprimido, corresponder a todas elas, de acordo com as exigências de cada uma.

Para alguns, a escola parece significar aceitação passiva. Para outros, o acesso a ela gera possibilidades de ascensão e até mesmo uma maneira de responder ao sistema socioeducativo a que foram judicialmente submetidos e que desejam com brevidade dele se afastar, em virtude das limitações que lhes são impostas no decorrer do cumprimento da medida socioeducativa.

Um dos pontos abordados na pesquisa tem como foco responder se os adolescentes estabelecem ou não uma relação entre o processo socioeducativo e a escola, podendo ser por meio dos conteúdos, abordagens, atividades e/ou reflexões realizadas. Nas respostas, fica claro que os entrevistados não enxergam semelhanças e, por vezes, em suas colocações, demonstram que os processos são opostos, quase antagônicos.

Nos relatos, nota-se que, na concepção dos adolescentes, a escola apresenta conteúdos formais como a leitura e escrita, conteúdos esses que, segundo aqueles, não contribuem de fato na preparação para a vida, diferente do valor atribuído por eles à medida socioeducativa, quando a colocam como um importante elemento de auxílio para seguir em frente na "caminhada da vida", ou seja, as ações realizadas com foco na responsabilização também atingem níveis de reflexão e conscientização.

Por outro lado, também consta nos discursos que o acompanhamento socioeducativo e o processo de escolarização ora são divergentes e outrora são complementares, ainda que na visão deles não dialoguem.

Nessa perspectiva, os dados coletados demonstram que a construção democrática de conhecimento está presente no discurso dos adolescentes acerca do processo socioeducativo, contrapondo-se a um modelo tradicional e mais fechado em si mesmo, levado a efeito nas instituições de ensino. Contudo, permite notar a ausência da intersetorialidade entre políticas 


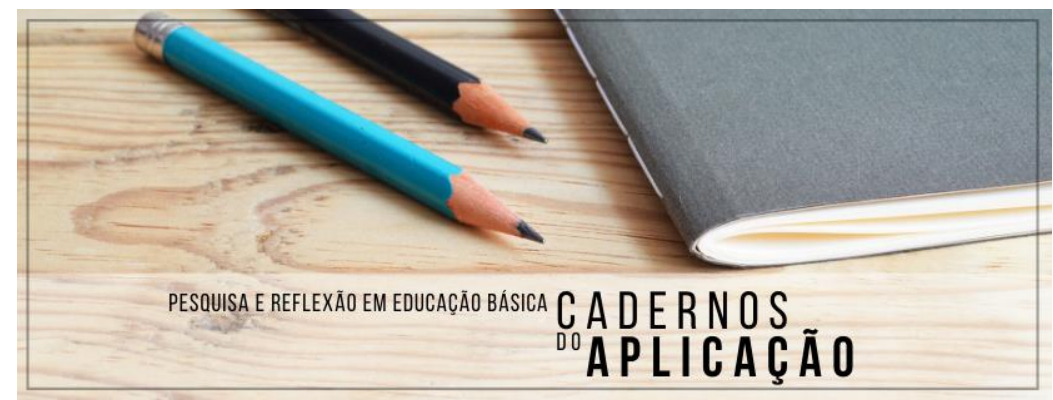

Cadernos do Aplicação

https://seer.ufrgs.br/CadernosdoAplicacao

Publicação Ahead of Print

ISSN 2595-4377 (online)

Porto Alegre | jul-dez. 2021 | v.34 | n.2

públicas básicas, alicerçando a falta de conhecimento das instituições de ensino acerca da vida de seus sujeitos extramuros escolares.

É uma pena que o caráter socializante da escola, o que há de informal na experiência que se vive nela, de formação ou deformação, seja negligenciado. Fala-se quase que exclusivamente do ensino de conteúdos, ensino lamentavelmente quase sempre entendido como transferência do saber. Creio que uma das razões que explica este descaso em torno do que ocorre no espaço-tempo da escola, que não seja a atividade ensinante, vem sendo uma compreensão estreita do que é educação e do que é aprender. (FREIRE, 1997, p. 49).

No que tange a dados quantitativos sobre a escolarização e que corrobora com os elementos dissertados acima, encontram-se no Relatório de Gestão do CASE (2019), quando apontam que no corrente ano foram atendidos 215 adolescentes no cumprimento das medidas socioeducativas em meio aberto, no ano de 2018, e, desse total, 99 encontravam-se fora da rede oficial de ensino. Entretanto, após receberem orientação, apoio e/ou participarem das ações técnicas, 77 retornaram aos estudos no início e/ou durante o processo socioeducativo.

Ainda no referido relatório, consta que as séries apresentadas pelos adolescentes no ano de 2018 demonstram que 58\% deles não possuem o ensino fundamental completo, 38\% possuem o ensino médio incompleto, $2 \%$ concluíram o ensino médio e/ou estão cursando o nível superior. Do total de atendidos, $42,25 \%$ não estavam matriculados na rede formal de ensino e, após as ações realizadas, foram matriculados nas seguintes esferas educacionais: $44 \%$ na educação municipal e 56\% na rede estadual de ensino.

Esse contexto educacional dos adolescentes atendidos pelo CASE, a priori, deveria soar como uma solução para as questões da evasão escolar, porém essa estratégia não garante o êxito do retorno e/ou permanência deles na educação regular. Uma situação paradoxal: de um lado, temos a fragilidade da educação estadual para gerir os possíveis conflitos e entraves existentes quando há adolescentes em cumprimento de medida socioeducativa na escola, principalmente nesse contexto social em que as escolas se encontram fechadas como medida de prevenção ao coronavírus. Do outro, a Educação de Jovens e Adultos (EJA), que, além de seguir outro processo metodológico, conceito e padrão de ensino, expõe os adolescentes à convivência escolar com pessoas de idade superior à sua, algo que, a longo prazo, pode contribuir para a 


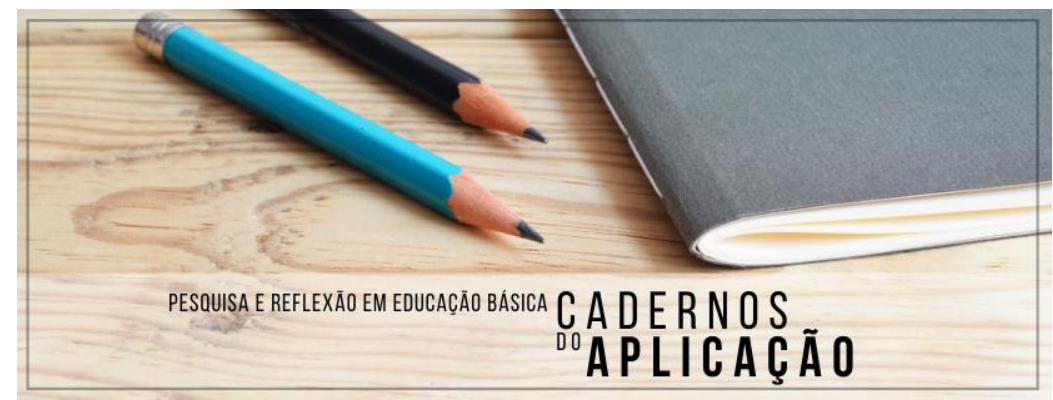

Cadernos do Aplicação

https://seer.ufrgs.br/CadernosdoAplicacao

Publicação Ahead of Print

ISSN 2595-4377 (online)

Porto Alegre | jul-dez. 2021 | v.34 | n.2

ruptura com o processo educacional, uma vez que eles estão inseridos em outro grupo de pertencimento.

As verbalizações dos adolescentes trazem à tona uma urgência em pensar sobre uma proposta reflexiva e crítica para solucionar as problemáticas metodológicas educacionais adotadas atualmente, especificamente quando se trata de adolescentes em cumprimento de medida socioeducativa na escola, uma vez que esse público é visto como aluno-problema e/ou descompromissado pela maior parte das unidades de ensino, propensos a desvincular-se com a educação.

Um dos pontos de culminância desse estudo é que demonstra a complexidade existente no atendimento aos adolescentes de modo geral e que de alguma maneira a pandemia da COVID-19, de forma inesperada, tornou viável o romper com modelos tradicionais de ensino e promove mudanças substanciais na busca por uma solução para enfrentar os processos excludentes escolares, transformações essas que, se bem geridas, podem oportunizar a instrumentalização dos profissionais da educação e o aparecimento de novas metodologias e teorias educacionais.

Salienta-se, para tanto, que é preciso uma educação humanizada e humanizadora, que vise à promoção da autonomia e possibilite aos indivíduos superar a naturalização de contradições sociais, os processos de alienação e os padrões dominantes da sociedade capitalista, para que assim seja possível a materialização de uma sociedade livre e, consequentemente, liberta dessas formas injustas e indignas de viver. Segundo Freire (1987), condição essa que pode ser superada quando adotada uma educação dialógica, em que a realidade e a cultura do sujeito são valorizadas, reconhecidas e difundidas.

Na perspectiva da concepção educacional dialógica, preconizada por Freire, como proposta participativa e emancipadora, Caliman (2010), descreve que a pedagogia social, que apresenta concepções distintas no cenário mundial, pode ser caracterizada no contexto brasileiro como uma pedagogia voltada para a assistência e/ou acompanhamento de casos que necessitem de ações preventivas e/ou compensatórias, bem como atuar frente às demandas sociais, entrelaçadas ao desenvolvimento do voluntariado nas instituições de acolhida, prevenção, recuperação, reinserção social, ou seja, “[...] uma pedagogia orientada para a ajuda 
e para o processo de empoderamento ou "empowerment" da solidariedade social e cidadã". (CALIMAN, 2010, p. 358).

A educação deve ser uma porta para um novo mundo, uma maneira para que o sujeito, historicamente excluído, possa se emancipar e se libertar. Maciel (2011), destaca que o reconhecimento da história de vida do indivíduo pode contribuir no processo de conscientização, dando-lhe condições para se libertar dos padrões hegemônicos impostos pela sociedade, além de promover a emancipação social.

Partindo dos desígnios descritos nas diversas obras da teoria freireana, cabe destacar que na Lei de Diretrizes e Bases da Educação Nacional (LDBEN), torna clara a existência de contextos educativos realizados fora da comunidade escolar, condições essas que a educação pode alinhar, dando ênfase ao legado trazido pela pedagogia e/ou educação popular, principalmente a desenvolvida a partir de 1970, tomando por base a influência do educador Paulo Freire.

Diante desse contexto geral sobre a escolarização, especificamente aqui tratando a escola em tempo de pandemia, far-se-á necessária uma reflexão crítica em torno do cerceamento da liberdade e da educação, buscando soluções que podem vir dos próprios estudantes, sejam eles adolescentes que cumprem ou não medidas socioeducativas. Aqui apresentamos um ponto de conclusão onde a pedagogia social, mesmo sendo uma área fora do sistema escolar, apresenta em seus princípios e na sua intencionalidade articulação com a educação, tendo em vista que o objeto da pedagogia social alemã traduz e dá sentido ao disposto no imperativo constitucional brasileiro, especificamente no Art. 205 da Constituição da República Federativa do Brasil (1988), da educação como direito de todos e dever do Estado e da família. Essa educação dialógica e libertadora vislumbra a conscientização do oprimido.

Nesse contexto de educação como um direito para todos, cabe mensurar que a interface entre a pedagogia social e a teoria freireana pode contribuir para que os adolescentes sejam atendidos de forma plena, tendo como base o rompimento dos processos de opressão, visibilidade aos excluídos e a potencialização das ações pedagógicas que devem ocorrer na execução das medidas socioeducativas. Sendo assim, encontra-se no SINASE a afirmação de que é "fundamental que o adolescente ultrapasse a esfera espontânea de apreensão da realidade 


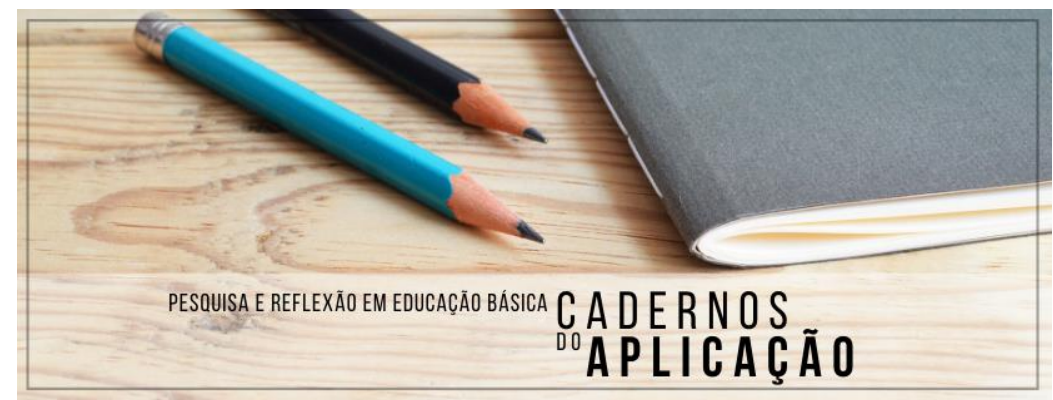

Cadernos do Aplicação

https://seer.ufrgs.br/CadernosdoAplicacao

Publicação Ahead of Print

ISSN 2595-4377 (online)

Porto Alegre | jul-dez. 2021 | v.34 | n.2

para chegar à esfera crítica da realidade, assumindo conscientemente seu papel de sujeito.” (BRASIL, 2006, p. 47).

Assim, por fim, considera-se que o ato educativo realizado no processo de acompanhamento escolar dos adolescentes no transcorrer do cumprimento das medidas socioeducativas, relaciona-se a outras nuances existentes na relação homem-mundo, aspectos que devem valorizar o processo socioeducativo, tendo em vista contribuir para que outras dimensões sejam abordadas nas ações sociopedagógicas, dentre elas: a vida econômica, social, cultural e política, focadas na perspectiva de efetivação de um processo que viabilize a autonomia e o exercício da cidadania como possibilidades de libertação.

\section{Considerações finais}

No presente estudo, como não podia deixar de ser, as discussões abordadas na entrevista acabaram por coletar também, sob a ótica dos adolescentes, a forma como eles enxergam a dicotomia entre o processo punitivo e o sociopedagógico, dando ênfase nos entraves promovidos pela desigualdade, discriminação e exclusão que podem ser interpretadas como ações reproduzidas por muitos atores do Sistema de Garantia de Direitos (SGD) e pelo sistema econômico vigente na atualidade, no qual os cidadãos e as cidadãs que vivem em conflitualidade com a justiça, como os próprios entrevistados, são expurgados da sociedade e invisibilizados.

Diante do universo complexo pelo qual percorreu esta investigação, desde o início do estudo, buscou-se como objetivo central a promoção de uma densa reflexão em torno de uma ciência que se encontra em processo de construção no Brasil, como a pedagogia social. Nesse sentido, ainda existem questões que precisam ser investigadas e, diante disso, faz-se necessário que a comunidade científica busque maiores esclarecimentos provenientes de outras investigações e/ou da práxis pedagógica estabelecida entre a prática da educação social e seu correspondente teórico, a pedagogia social, quando adotadas no contexto das medidas socioeducativas.

Ainda nesse sentido, cabe também propor uma reflexão no que tange ao (re)ingresso e à permanência dos adolescentes que cumprem medida, na escola, partindo da centralidade de 


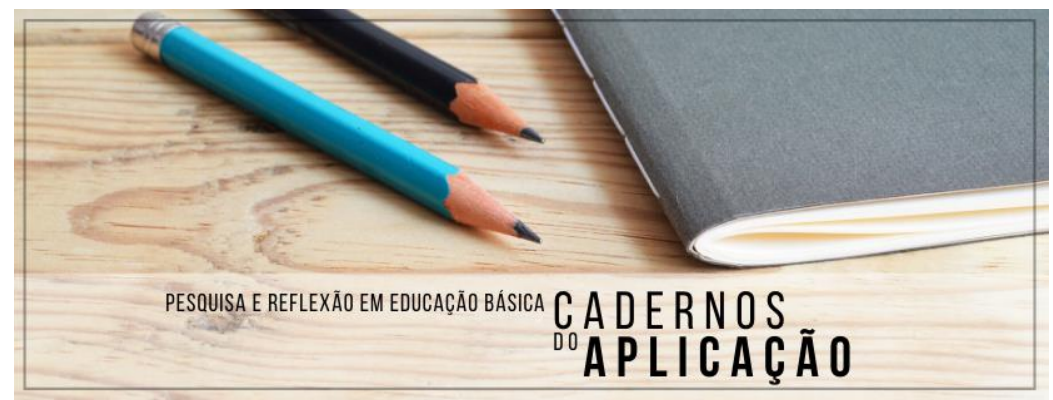

Cadernos do Aplicação

https://seer.ufrgs.br/CadernosdoAplicacao

Publicação Ahead of Print

ISSN 2595-4377 (online)

Porto Alegre | jul-dez. 2021 | v.34 | n.2

que é um dos elementos presentes e descritos na determinação judicial, expedida pela Vara da Infância e da Juventude. Nesse caso, é a prática na Comarca de São Bernardo do Campo, que aponta nos ofícios a obrigatoriedade da matrícula e frequência regular em estabelecimento oficial de ensino, com demonstração de bom aproveitamento.

No processo de levantamento bibliográfico, ficou claro que não dispomos de um número expressivo de materiais acadêmicos que abordem a relação entre a pedagogia social, teoria freireana e a sua relação com a escolarização de adolescentes em conflito com a lei. Nessa perspectiva de refletir sobre a história e reavivar o espírito de luta em prol da equidade de direitos, pode-se destacar que, no desenvolvimento desta investigação, fomos surpreendidos ao perceber que a maioria dos adolescentes que participaram desse estudo, não denotaram criticidade ao responder às questões, mesmo sendo um assunto presente no cotidiano deles.

Contudo, aproveitamos esta conclusão para explanar a dificuldade encontrada na qualificação de documentos, materiais e pesquisas que trazem a medida socioeducativa e a sua relação com a escola, especificamente na ótica dos adolescentes, por isso, faz-se necessário que as novas investigações viabilizem aos leitores uma análise crítica em relação ao tema, proporcionando assim, elementos plausíveis para a troca de lentes e uma nova interpretação desse universo que, por vezes, é tratado sem levar em consideração o contexto social, por isso, reitera-se a importância de olhar o objeto de estudo com equidade e responsabilidade, principalmente quando se trata de adolescentes em fase peculiar de desenvolvimento.

\section{Referências}

BOURDIEU, Pierre. A miséria do mundo. Tradução de Mateus S. Soares. 3a edição. Petrópolis: Vozes, 1999.

BRASIL. Constituição da República Federativa do Brasil. Brasília: Senado Federal, Subsecretaria de Edições Técnicas, 1988.

Estatuto da Criança e do Adolescente (ECA). Brasília: Ministério da Justiça, Secretaria de Estado dos Direitos Humanos, 1990.

Secretaria Especial dos Direitos Humanos. Sistema Nacional de Atendimento Socioeducativo - SINASE/ Secretaria Especial dos Direitos Humanos - SEDH/ PR. Brasília DF: CONANDA, 2006. 


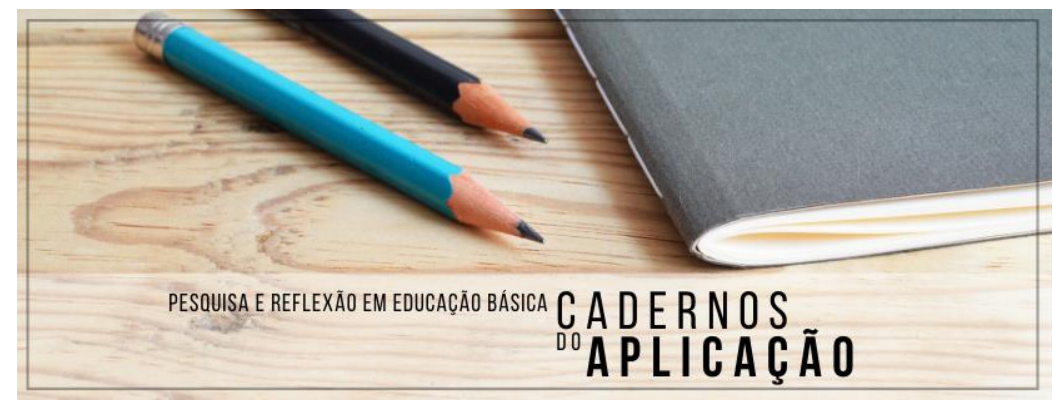

Cadernos do Aplicação https://seer.ufrgs.br/CadernosdoAplicacao

Publicação Ahead of Print

ISSN 2595-4377 (online)

Porto Alegre | jul-dez. 2021 | v.34 | n.2

Ministério do Desenvolvimento Social e Combate à Fome. (Resolução No 109 de Novembro de 2009) - Tipificação Nacional de Serviços Socioassistenciais. Brasília, DF. 2009. Índice Paulista de Vulnerabilidade Social - IPVS. Fundação SEADE, 2010.

Plano Nacional de Atendimento Socioeducativo: Diretrizes e eixos operativos para o SINASE. Brasília: Secretaria de Direitos Humanos da Presidência da República, 2013.

Plano Nacional de Educação - Lei do PNE (n $\left.n^{o} 13.005 / 2014\right)$. Ministério da Educação / Secretaria de Articulação com os Sistemas de Ensino (MEC/ SASE), 2014.

CABANAS, José Maria Quintana. Antecedentes históricos de la educación social. In: PETRUS, Antonio (Org.). Pedagogia Social. Espanha: Ariel, p. 70- 90, 1997.

CALIMAN, Geraldo. Pedagogia Social: seu potencial crítico e transformador. Revista de CIÊNCIAS da EDUCAÇÃO - UNISAL - Americana/SP - Ano XII - Nº 23, p. 341-368, 2010.

Fundamentos teóricos e metodológicos da pedagogia social na Europa (Itália). In: I CONGRESSO INTERNACIONAL DE PEDAGOGIA SOCIAL, 2006.

CARRERAS, Juan Sáez. Q. La construcción de la pedagogía social: algunas vías de aproximación. In: PETRUS, Antonio. (org.). Pedagogia Social. Espanha: Ariel, p. 40-101, 1997.

CENTRO DE ATENDIMENTO SOCIOEDUCATIVO - CASE. Relatório de Gestão Anual do Centro de Atendimento Socioeducativo. São Bernardo do Campo: Fundação Criança de São Bernardo do Campo, 2019.

. Plano de Trabalho do Centro de Atendimento Socioeducativo (Relatório de Gestão Anual). São Bernardo do Campo: Fundação Criança de São Bernardo do Campo, 2020.

FREIRE, Paulo. Educação como prática da Liberdade. Ed. Rio de Janeiro: Paz e Terra, 1979. . Pedagogia da autonomia. São Paulo: Paz e Terra, 1997. . Pedagogia do Oprimido. 17. ed. Rio de Janeiro: Paz e Terra, 1987. Política e educação. 5. ed. São Paulo: Cortez, 2001.

LÓPEZ, Susana Torío. La Pedagogía Social en España. In: MOURA, Rogério; NETO, João Clemente de Souza; SILVA, Roberto da. (Orgs.). Pedagogia Social. São Paulo: Expressão \& Arte Editora, p. 97-98, 2009,

MACHADO, Erico Ribas. Fundamentos da pedagogia social. Ponta Grossa, Editora Unicentro, p. 15-21, 2013.

MACIEL, Karen de Fátima. O pensamento de Paulo Freire na trajetória da educação popular. Educação em Perspectiva, Viçosa, v. 2, n. 2, p. 326-344, jun./dez. 2011. 


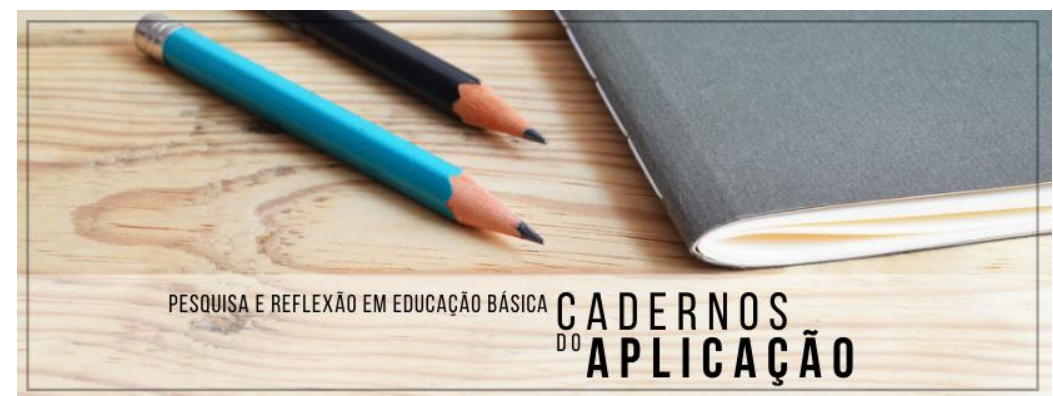

Cadernos do Aplicação

https://seer.ufrgs.br/CadernosdoAplicacao

Publicação Ahead of Print

ISSN 2595-4377 (online)

Porto Alegre | jul-dez. 2021 | v.34 | n.2

MARX, Karl; ENGELS, Friedrich. A ideologia alemã. Tradução de Luís Claudio de Castro e Costa. 3. ed. São Paulo: Martins Fontes, 1993.

NATORP, Paul. Pedagogía Social: teoría de la educación de la voluntad. Madrid: La Lectura, p. 96-98, 1913.

PÉREZ SERRANO, Gloria. Pedagogía social educación social: construcción científica e intervención práctica. Madrid: Narcea, p. 49, 2004.

PETRUS, Antonio. Pedagogia Social. Espanha: Ariel, 1997.

PINTO, Patrícia da Silva; SILVA, Raquel Assunção Silveira. Socioeducação: que prática é essa? In: PAIVA, Ilana Lemos de; SOUZA. Candida; RODRIGUES, Daniela Bezerra (Orgs.). Justiça juvenil: teoria e prática no sistema socioeducativo. Natal: Editora da UFRN, p. 141160, 2014.

SEVERINO, Antônio Joaquim. Metodologia do trabalho científico. 24. ed. São Paulo: Cortez, p.135, 2016.

SILVA, Ivani Ruela de Oliveira; SALLES, Leila Maria Ferreira. Adolescente em liberdade assistida e a escola. Estudos de Psicologia. Campinas, [online], v. 28, n. 3, p. 353-362, 2011.

SILVA, Roberto de. As bases científicas da educação não-formal. In: MOURA, Rogério; NETO, João Clemente de Souza; SILVA, Roberto da. (Orgs.). Pedagogia Social. São Paulo: Expressão \& Arte Editora, p. 161, 2009.

SILVA, Roberto da. Pedagogia social. São Paulo: Expressão \& Arte, 2012.

SOUZA NETO,. João Clemente de. Crianças e adolescentes abandonados, estratégias de sobrevivência. São Paulo: Expressão \& Arte, p. 67, 2001.

. João Clemente de; LIBERAL, Márcia Melo Costa. Educar para o trabalho. Estudos sobre os novos paradigmas. São Paulo, Arauco, 2006.

TRILLA, Jaume. La Educación Fuera de la Escuela. Ámbitos no formales y educación social. Barcelona. Ariel, p. 30, 1996.

Data de submissão: 31/01/2021

Data de aceite: $23 / 02 / 2021$

DOI: https://doi.org/10.22456/2595-4377.111207 